\title{
METODOLOGI PENGAWASAN DENGAN PENDEKATAN AGAMA DALAM DUNIA PENDIDIKAN
}

\author{
Miftahul Ulum \\ STAI Syaichona Moh. Cholil Bangkalan \\ miftahul_ulum2001@yahoo.com
}

\begin{abstract}
ABSTRAK
Supervisi dengan pendekatan agama merupakan salah satu bentuk pengawasan melalui upaya pemberdayaan dan penanaman nilai-nilai agama untuk mendorong seseorang agar menjadi pribadi yang bersih dan bebas tipu daya sehingga mampu menjalankan tugas dengan jujur, totalitas, dan penuh tanggung jawab. Dengan begitu, akan meminimalisir adanya penyimpangan-pemyimpangan. Penanaman dan pengamalan nila-nilai ibadah merupakan hal yang sangat esensial bagi pengawas dalam melaksanakan tupoksinya, karena melalui nilai-nilai ibadah dapat dijadikan prinsip sebagai prinsip dasar dalam bekerjadapat menggerakkan hati nurani para guru supaya dapat bekerja dengan penuh disiplin dan tanggung jawab. Dan untuk menjadi pengawas, seseorang harus memiliki standar kualifikasi dan kompetensi sebagaimana didefinisikan dalam Permendiknas No. 12 tahun 2007 tentang standar pengawas sekolah/madrasah. Selain itu, tugas pengawasan juga membutuhkan sumber daya etika atau peraturan sebagai pedoman untuk menjaga martabat dan kualitas sekolah sehingga tidak ada pihak yang dirugikan. Penelitian ini menggunakan metode kualitatif dengan pendekatan kajian pustaka. Dan hasil penelitiannya menunjukkan bahwa pengawasan dengan pendekatan agama dapat dilakukan melalui pendekatan rasional, pendekatan afektif, pendekatan pembiasaan, dan pendekatan keteladanan. Selain itu, pengimplementasian Pengawasan dengan Pendekatan Agama juga bisa dilakukan dengan berpegang teguh pada lima prinsip, yaitu: bekerja semata-mata karena-Nya, bekerja sebagai sarana komunikasi dengan-Nya, lambang ketundukan dan ketaatan pada-Nya, semua pekerjaan dinilai sebagai ibadah, tidak mengenal waktu dan tempat dalam bekerja untuk meningkatkan kinerja guru.
\end{abstract}

Kata Kunci: pengawasan, pendekatan keagamaan, pendidikan. 


\begin{abstract}
Supervision with a religious approach is a form of supervision through empowerment efforts and inculcation of religious values to encourage someone to become a clean and deceit-free person so that they are able to carry out their duties with honesty, totality and full responsibility. That way, it will minimize any deviations. Planting and practicing the values of worship are very essential for supervisors in carrying out their main duties, because the values of worship can be used as a principle as a basic principle in working, acting and acting so that they become a moral force for supervisors when exercising the conscience of teachers Can work with full discipline and responsibility and free from any deviation from the task at hand. And to become a supervisor, a person must have standard competencies and competencies defined in Permendiknas No. 12 of 2007 concerning the standards for school / madrasah supervisors. In addition, the task of supervision also requires new ethical or regulatory resources to maintain the dignity and quality of the school so that no party is disadvantaged. This study uses a qualitative method with a literature review approach. And the results of his research indicate that supervision with a religious approach can be done through a rational approach, affective approach, habitual approach, and exemplary approach. In addition, the implementation of Supervision with a religious approach can also be done by adhering to the principles, namely: working individually for God, working as a means of communication with God, a symbol of submission and obedience to God, all work as worship, not knowing time and place in work to improve teacher performance.
\end{abstract}

Keywords: supervision, religious approach, education.

\title{
A. PENDAHULUAN
}

Titik berat pembangunan pendidikan era sekarang ditekankan pada peningkatan mutu. Konsekuensinya, perlu ditingkatkan keseluruhan komponen sistem pendidikan, baik yang bersifat human resources ${ }^{l}$

${ }^{1}$ Komponen-komponen sistem pendidikan yang bersifat human resources dapat digolongkan menjadi tenaga pendidik dan pengelola satuan pendidikan, penilik, pengawas, peneliti dan pengembang di bidang pendidikan, pustakawan, laboran dan teknisi sumber belajar. Lihat Ali Imron, Supervisi Pembelajaran Tingkat Satuan Pendidikan (Jakarta: Bumi Aksara, 2012), 2. 
maupun yang bersifat material resources demi tercapainya tujuan pendidikan. $^{2}$

Setiap organisasi tentunya menghendaki semua tujuan-tujuan yang telah ditetapkan dapat tercapai secara optimal. Akan tetapi, upaya pencapaian tujuan yang dimanifestasikan dalam program dan kegiatankegiatan tersebut tidak selamanya berjalan mulus, selalu saja ada faktor penghambat yang membuat semuanya tidak bisa berjalan sesuai rencana. Dan apabila ketidaksesuaian atau penyimpangan pelaksanaan program dan kegiatan dibiarkan, maka organisasi akan sangat merugi. Untuk itulah maka perlu dilakukan sebuah pengawasan terhadap pelaksanaan program dan kegiatan. ${ }^{3}$

Supervisi yang kemudian lebih dikenal dengan pengawasan ini, terbukti memang banyak memberikan pengaruh baik khususnya dalam perkembangan pendidikan. Seperti halnya memicu para pendidik memiliki kemampuan mendidik yang kreatif, aktif, dan inovatif. Oleh sebab itu, pendidikan harus diawasi atau disupervisi, yang mana hal ini biasanya dilakukan oleh para kepala sekolah atau pengawas-pengawas lain yang ada di departemen pendidikan dengan cara memberikan pengarahan-pengarahan yang baik dan bimbingan serta masukan tentang cara atau metode mendidik yang baik dan profesional. Dengan demikian, kinerja para pendidik dan pegawai sekolah lainnya bisa meningkat. ${ }^{4}$

Dalam konteks desentralisasi pendidikan, pengawas merupakan penjamin, peningkat, dan pengawas mutu pendidikan yang memiliki keunggulan kompetitif dan komparatif. ${ }^{5}$ Namun, mirisnya dalam mengemban tugas tersebut tak terlepas dari berbagai problematika bahkan mengacu pada hasil penelitian yang dilakukan oleh Sudirman, Murniati AR, dan Bahrun sebagaimana yang tertuang dalam Jurnal Magister Administrasi Pendidikan beliau menyatakan bahwa Jabatan

${ }^{2}$ Imron, Supervisi Pembelajaran, 1.

${ }^{3}$ Setyowati, Organisasi dan Kepemimpinan Modern (Yogyakarta: Graha Ilmu, 2013), 151.

${ }^{4}$ Miftahul Ulum, "Metodologi Studi Islam (Spiritualitas Dalam Pendidikan Islam Dalam Pandangan Syed Muhammad Naquib Al-Attas)", Al-Iman: Jurnal Studi Keislaman dan Kemasyarakatan, Vol. 4 Nomor 1 (22 Maret 2020): 1-21.

5 Sudirman, Murniati AR dan Bahrun, "Manajemen Pengawas Pada Kantor Kementerian Agama Kabupaten Simeulue", Jurnal Magister Administrasi Pendidikan, Vol. 5 No.3, (Agustus, 2017), 156. 
pengawas sebagai jabatan karir tertinggi bagi seorang guru telah menjadi jabatan yang kurang menarik bagi para guru dalam menjalani tugas fungsionalnya. Kenyataan ini secara tidak langsung telah menimbulkan persepsi negatif bahwa jabatan pengawas merupakan jabatan hukuman dan tempat parkir bagi guru-guru bermasalah. ${ }^{6}$

Sejalan dengan hal tersebut, Herman dan Jamaluddin Idris dalam journal of islamic education juga menyatakan bahwa banyak persoalan yang muncul dikalangan para pengawas saat melaksanakan tupoksi supervisi seperti halnya kurang mampu mengoprasionalkan nilai-niai ibadah pada saat melaksanakan tupoksi, padahal secara teoritis seorang pengawas khususnya pengawas PAI harus memiliki prinsip ibadah dalam bekerja. Menurut mereka, penanaman dan pengamalan nila-nilai ibadah merupakan hal yang sangat esensial bagi pengawas dalam melaksanakan tupoksi khususnya bagi pengawas PAI. Karena melalui nilai-nilai ibadah dapat dijadikan prinsip sebagai prinsip dasar dalam bekerja, bertindak dan berbuat sehingga menjadi kekuatan moral bagi pengawas pada saat menggerakkan hati nurani para guru supaya dapat bekerja dengan penuh disiplin dan tanggung jawab serta terbebas dari segala penyimpangan terhadap tugas yang diembannya. ${ }^{7}$

Berdasar pada hal tersebut maka melalui pengawasan dengan pendekatan agama diharapkan dapat memberikan kesadaran kepada para guru dan untuk melaksanakan tugasnya dengan mengacu pada peraturan yang sudah ditetapkan dan diberlakukan, memiliki daya tangkal dan kontrol untuk membangun kejujuran, keterbukaan, keadilan, ketulusan serta tidak membuka ruang sedikit pun untuk melakukan perbuatanperbuatan tercela yang pada dasarnya diharamkan atau dilarang oleh setiap ajaran agama. ${ }^{8}$

\footnotetext{
${ }^{6}$ Ibid., 159.

${ }^{7}$ Herman dan Jamaluddin Idris, "Pendekatan Ibadah sebagai Model Supervisi untuk Meninglatkan Kinerja Guru Pendidikan Agama Islam”, DAYAH: Journal of Islamic Education, Volume 3 No.1, (2020), 78.

${ }^{8}$ Miftahul Ulum, "The Concept of Maslahah By Al-Imam Malik And Al-Imam AlTufi (Comparatif Study of Maslahah Al-Imam Malik and Al-Imam Najm al-Din Al-Tufi)", Veteran Law Review, Vol. 2, No. 1 (November, 2018), 58.
} 


\section{B. PENGERTIAN PENGAWASAN}

Dalam Kamus Besar Bahasa Indonesia kata pengawasan memiliki arti Penilikan dan penjagaan. ${ }^{9}$ Pengawasan juga sering kali di identikkan dengan supervisi.

Secara etimologis, istilah supervisi dialih bahasakan dari bahasa Inggris Supervision yang terdiri dari dua suku kata, yakni 'super" yang berarti atas atau lebih dan "vision" yang berarti lihat atau awasi. ${ }^{10}$ Namun, Dr. Wahyudi berpendapat lain, ia menyatakan bahwa istilah supervisi berasal dari bahasa latin "supervideo" yang artinya mengawasi (oversee), atau menilai kinerja bawahan. ${ }^{11}$

Sedangkan secara terminologi, Pengawasan adalah suatu usaha atau aktivitas yang mengupayakan agar kegiatan-kegiatan atau aktivitas yang dilakukan dapat tercapai sesuai yang direncanakan dan diprogramkan. Dengan kata lain, perencanaan yang merupakan fungsi pertama dalam manejemen tersebut benar-benar berlaku dalam praktik dan tercapai maksudnya. ${ }^{12}$ Sejalan dengan itu, E. Mulyasa juga mengemukakan bahwa pengawasan mengandung arti suatu kegiatan untuk melakukan pengamatan agar pekerjaan dilakukan sesuai dengan ketentuan. ${ }^{13}$

Dari pengertian-pengertian tersebut, penulis menyimpulkan bahwa pengawasan adalah sebuah upaya pengamatan yang dilakukan oleh seorang atasan terhadap bawahannya dengan tujuan untuk melakukan pembenahan melalui bimbingan, pembinaan, dan pengarahan terhadap personil (pelaku) atau lembaga pendidikan sehingga tujuan dan rencana yang sudah ditetapkan bisa terlaksana sesuai dengan harapan.

Istilah pengawasan terdapat dalam beberapa surat dan ayat $\mathrm{Al}-$ Qur'an serta dalam hadits Nabi saw, sebagaimana yang ditermaktub dalam QS. Al-fajr ayat 14: "sesungguhnya Tuhanmu benar-benar

9 Tim Penyusun Kamus Pusat Bahasa, Kamus Besar Bahasa Indonesia, offline (Jakarta: Pusat Bahasa, 2008), 108.

${ }^{10}$ Murip Yahya, Profesi Tenaga Kependidikan (Bandung: Pustaka Setia, 2013), 109.

${ }^{11}$ Wahyudi, Kepemimpinan kepala Sekolah dalam Organisasi Pembelajar (Learning Organization) (Bandung: Alfabeta, 2012), 97.

12 Ali Imron, Proses Manajemen Tingkat Satuan Pendidikan (Jakarta: Bumi Aksara, 2013), 138.

${ }^{13}$ E. Mulyasa, Manajemen Berbasis Sekolah (Bandung: PT Remaja Rosdakarya, 2012), 154. 
mengawas”, QS. Qaf ayat 16-18: "Dan Dialah Allah yang disembah baik dilangit maupun dibumi. Dia mengetahui segala yang kamu rahsiakan dari segala yang kamu lahirkan dan mengetahui pula segala yang kamu usahakan. Dan juga Sabda Nabi: "Setiap anak adam mempunyai kesalahan, dan sebaik-baik yang mempunya kesalahan adalah mereka yang bertaubat". (HR. Tirmidzi dan Ibnu Majah). ${ }^{14}$

Dalam istilah robbun mempunyai dua arti penting bagi umat Islam, yaitu Tuhan Yang Maha Mengawasi dan Maha Pembimbing tarbiyah. Sehingga, program pengawasan dalam perspektif Islam ini adalah dalam rangka memberikan dorongan kesadaran diri (self counsiousness) dan pengawasan menjadi perilaku yang melekat, membudaya, dan merupakan kebutuhan dalam kehidupan berbangsa, bermasyarakat, dan bernegara. ${ }^{15}$

\section{TUJUAN PENGAWASAN}

Tujuan pengawasan secara umum adalah untuk mengendalikan kegiatan agar sesuai dengan rencana yang telah ditetapkan sehingga hasil pelaksanaan pekerjaan diperoleh secara efisien dan efektif sesuai dengan rencana yang telah ditentukan dalam program kegiatan. ${ }^{16}$ Dengan demikian, apabila supervisi/pengawasan ini dilaksanakan dengan baik, peningkatan kinerja semua komponen pendidikan akan menjadi baik, peran guru dan tanggung jawab guru sebagai tenaga edukatif pun semakin meningkat. ${ }^{17}$

Adapun tujuan pengawasan dalam Islam, Dr. Atiqullah, M. Pd dalam bukunya yang berjudul Manajemen dan Kepemimpinan Pendidikan Islam merumuskannya sebagai berikut: ${ }^{18}$

${ }^{14}$ Atiqullah, Manajemen \& Kepemimpinan Pendidikan Islam (Pamekasan: STAIN Pamekasan Press, 2010), 34.

${ }^{15}$ Ibid., 33.

${ }^{16}$ Kompri, Manajemen Pendidikan: Komponen-Komponen Elementer Kemajuan Sekolah (Yogyakarta: Ar-Ruzz Media, 2015), 283.

17 Jasmani \& Syaiful Mustofa, Supervisi Pendidikan: Terobosan Baru dalam Peningkatan Kinerja Pengawas Sekolah dan Guru (Yogyakarta: Ar-Ruzz Media, 2013), 31.

18 Atiqullah, Manajemen \& Kepemimpinan Pendidikan : Strategi Mengefektifkan Lembaga Pendidikan Agama \& Pendidikan Keagamaan (Surabaya: Pena Salsabila, 2012), 48. 
1. Terwujudnya pemahaman tentang makna dan arti penting pengawasan dengan berlandaskan nilai-nilai agama Islam dalam penyelenggaraan pendidikan,

2. Terwujudnya prakarsa dan peran aktif pengawasan khususnya anggota organisasi sehingga menumbuhkan kedisiplinan dan kinerja berkualitas, karena bekerja merupakan bagian dari pengabdian kepada masyarakat dan bagian dari ibadah kepada Allah SWT.,

3. Terwujudnya kemampuan pengendalian nafsu dan kesadaran diri bahwa kita senatiasa diawasi oleh Yang Maha Kuasa dan akan mempertanggung jawabkan pelaksanaan tugas di dunia dan akhirat nanti.

Dari tujuan-tujuan tersebut, bisa dikatakan bahwa tujuan supervisi pendidikan adalah meningkatkan kemampuan profesional dan teknis bagi guru, kepala sekolah, dan personel sekolah lainnya agar proses pendidikan disekolah lebih berkualitas. Dan yang utama, supervisi pendidikan dilakukan atas dasar kerjasama, partisipasi, dan kolaborasi, bukan paksaan dan kepatuhan. Dengan demikian, akan timbul kesadaran, inisiatif, dan kreativitas personel sekolah. ${ }^{19}$

\section{FUNGSI PENGAWASAN}

Fungsi diartikan sebagai tugas aktif dari kegiatan supervisi yang dilakukan oleh orang yang berkedudukan sebagai supervisor. Menurut Olivia sebagaimana yang dikutip oleh Wahyudi, fungsi Supervisi terbagi menjadi tiga, yaitu: pengembangan staf, pengembangan kurikulum, dan perbaikan pengajaran. ${ }^{20}$

Menurut Mulyasa, peran supervisor adalah mendukung, membantu, dan membagi, bukan menyuruh. Jadi, supervisi yang baik menurut Wiles sebagaimana yang dikutip E. Mulyasa hendaknya mengembangkan kepemimpinan ${ }^{21}$ di dalam kelompok, membangun

\footnotetext{
${ }^{19}$ Wahyudi, Kepemimpinan kepala Sekolah, 101.

${ }^{20}$ Ibid.

${ }^{21}$ Pemimpin yang bermutu menurut Ajaran Agama Islam hendaknya berpegang teguh pada aturan-aturan berikut: memiliki niat yang lurus, laki-laki, tidak meminta jabatan, berpegang pada hukum Allah, memutuskan perkara dengan adil, tidak menutup diri saat diperlukan rakyat, menasehati rakyat, tidak menerima hadiah, lemah lembut. Lihat Jerry $\mathrm{H}$. Makawimbang, Kepemimpinan Pendidikan yang Bermutu (Bandung: Alfabeta, 2012), 104.
} 
program latihan dalam jabatan untuk meningkatkan keterampilan dan kemampuan guru dalam menilai hasil pekerjaanya. ${ }^{22}$

\section{E. STANDAR KUALIFIKASI PENGAWAS}

Untuk diangkat sebagai pengawas sekolah, seseorang harus memenuhi kualifikasi yang sudah ditentukan. Permendiknas No. 12 Tahun 2007 tentang Standar Pengawas Sekolah/Madrasah menetapkan Kualifikasi dan kompetensi yang harus dimiliki pengawas sekolah. Kualifikasi pengawas sekolah sesuai dengan Permendiknas tersebut sebagai berikut:

1. Berpendidikan minimum sarjana (S1) atau diploma empat (D-1V) kependidikan dari perguruan tinggi terakresitasi bagi pengawas TK/RA dan SD/MI. Dan memiliki pendidikan minimum magister (S2) kependidikan dengan berbasis sarjana (S1) dalam rumpun mata pelajaran yang relevan pada perguruan tinggi terakreditasi bagi pengawas SMP/MTs, SMA/MA, dan SMK/MAK.

2. Memiliki sertifikat pendidik sesuai jenjang pendidikan yang diawasi. Dan memiliki pengalaman kerja minimal 4 tahun bagi kepala sekolah, dan 8 tahun bagi guru.

3. Memiliki pangkat minimum penata, golongan ruang III/c.

4. Berusia setinggi-tingginya 50 tahun, sejak diangkat sebagai pengawas di satuan pendidikan.

5. Memiliki kompetensi sebagai pengawas satuan pendidikan yang dapat diperoleh melalui uji kompetensi dan atau pendidikan dan pelatihan fungsional pengawas pada lembaga yang ditetapkan pemerintah.

6. Lulus seleksi pengawas satuan pendidikan. ${ }^{23}$

Adapun kompetensi ${ }^{24}$ yang harus dimiliki seorang pengawas meliputi: kompetensi kepribadian, kompetensi supervisi manajerial,

\footnotetext{
${ }^{22}$ E. Mulyasa, Manajemen Berbasis Sekolah, 156.

${ }^{23}$ Barnawi \& Muhammad Arifin, Meningkatkan Kinerja Pengawas Sekolah: Upaya Upgrade Kapasitas Kerja Pengawas Sekolah (Yogyakarta: Ar-Ruzz Media, 2014), 13-15.

${ }^{24}$ Kompetensi pengawas merupakan himpunan pengetahuan, kemampuan, dan keyakinan yang dimiliki pengawas dan ditampilkan dalam tindakannya untuk peningkatan mutu pendidikan/sekolah. Lihat Kompri, Manajemen Pendidikan, 293.
} 
kompetensi supervisi akademik, kompetensi evaluasi pendidikan, kompetensi penelitian pengembangan, dan kompetensi sosial. ${ }^{25}$

\section{F. PEDOMAN PELASANAAN PENGAWASAN}

Menurut Herabudin, dalam supervisi Pendidikan terdapat beberapa pedoman utama yang harus dipegang terkait cara kerja supervisi yang merupakan fungsi supervisi itu sendiri. Adapun pedoman tersebut, antara lain: ${ }^{26}$

1. Mengadakan evaluasi terhadap pelaksanaan kurikulum dengan segala sarana dan prasarananya

2. Membantu serta membina guru/kepala sekolah dengan cara memberikan petunjuk, penerangan, dan pelatihan agar mereka dapat meningkatkan keterampilan dan kemampuan mengajarnya

3. Membantu kepala sekolah/guru untuk menghadapi dan menyelesaikan masalah.

Lebih lanjut Herabudin menyatakan bahwa tiga pedoman tersebut mengisyaratkan bahwa tata kerja yang harus dilakukan dalam melaksanakan supervisi pendidikan berkaitan dengan hal-hal berikut:

1. Supervisi adalah pelayanan seluruh kegiatan pembelajaran dan pengadministrasiannya secara akademik.

2. Penelitian terhadap semua aktivitas pembelajaran yang berkaitan dengan keadaan sarana prasarana belajar, keadaan siswa, kemajuan prestasi akademik siswa, permasalahan yang dihadapi sekolah dan seluruh aktivitasnya, pencarian solusi masalah dan penerapan serta pelaksanaan model baru untuk mengembangkan proses pembelajaran yang lebih baik.

3. Pengawasan akademik dan pengadministrasiannya.

4. Evaluasi terhadap semua yang berkaitan dengan pendidikan, yaitu kaitannya dengan guru dan kinerjanya, kurikulum, anak didik, alatalat pendidikan, sistem evaluasi, dan kelembagaan lainnya.

${ }^{25}$ Barnawi \& Muhammad Arifin, Meningkatkan Kinerja Pengawas Sekolah, 15.

${ }^{26}$ Herabudin, Administrasi dan Supervisi Pendidikan (Bandung: Pustaka Setia, 2009), 234. 
5. Penertiban kesesuaian jabatan dan tugas para karyawan, staf, para guru, dan seluruh pihak terkait". ${ }^{27}$

Selain mengacu pada pedoman-pedoman tersebut, dalam menjalankan tugas kepengawasan juga perlu adanya sumber etika atau aturan yang dapat dijadikan pedoman, demi menjaga martabat dan mutu profesi pengawas sekolah sehingga tidak merugikan pihak manapun. Sumber etika atau aturan itu dalam suatu organisasi profesi dikenal dengan kode etik profesi.

Adapun kode etik pengawas sekolah antara lain:

1. Dalam melaksanakan tugas, senantiasa berlandaskan iman dan takwa, serta mengikuti perkembangan ilmu pengetahuan dan teknologi

2. Merasa bangga mengemban tugas sebagai pengawas sekolah

3. Memiliki pengabdian yang tinggi dalam menekuni tugas sebagai sebagai pengawas sekolah

4. Bekerja dengan penuh rasa tanggung jawab dalam tugasnya sebagai pengawas sekolah

5. Menjaga citra dan nama baik selaku pembina dalam melaksanakan tugas sebagai pengawas sekolah

6. Memiliki disiplin yang tinggi dalam melaksanakan tugas profesi sebagai pengawas sekolah

7. Mampu menampilkan keberadaannya sebagai aparat dan tokoh yang diteladani

8. Sigap dan terampil untuk menanggapi dan membantu memecahkan masalh-masalah yang dihadapi aparat binaannya

9. Memiliki rasa kesetiakawanan sosial yang tinggi, baik terhadap aparat binaan maupun terhadap sesama pengawas sekolah. ${ }^{28}$

\section{G. IMPLEMENTASI PENGAWASAN DENGAN PENDEKATAN AGAMA}

Pengawasan dengan pendekatan agama (PPA) adalah bentuk pengawasan dini melalui pemberdayaan nilai-nilai agama, sebagai alternatif model pengembangan fungsi pengawasan fungsional, dalam

\footnotetext{
${ }^{27}$ Ibid., 234-235.

${ }^{28}$ Barnawi \& Muhammad Arifin, Meningkatkan Kinerja Pengawas Sekolah, 59.
} 
mendorong terciptanya pengawasan diri (self control) dan jati diri aparatur pemerintah yang bersih dan terhindar dari penyimpangan.

Dari pengertian tersebut dapat dipahami hakikat PPA sebagai berikut:

1. PPA merupakan konsep memadukan antara manajemen pemerintahan dengan nilai spiritual yang dapat diaplikasikan pada manajemen diri, keluarga, masyarakat dan pemerintahan.

2. PPA adalah sebuah model yang memberikan tuntunan dan menampilkan metodologi praktis tentang pemberdayaan nilai spiritual dan penjernihan hati nurani. Hasilnya diharapkan dapat mendorong terciptanya SDM yang tangguh secara spiritual, memiliki self control yang kuat, sehingga tercipta kemapanan seluruh komponen internal pemerintahan yang efektif dan efisien.

3. PPA dibangun dan digerakkan oleh nilai spiritual, nilai kesucian dan nilai ketuhanan. Nilai tersebut diinternalisasikan dengan nilai kode etik pegawai negeri sipil. Kemudian merefleksi dalam aksi amal (ihsan) yang diwujudkan dalam bentuk kinerja profesional, inovatif, disiplin, amanah dan akuntabel.

4. PPA berorientasi kepada hasil, dengan indikator pelaksanaan tugas berdasarkan ketentuan peraturan perundang-undangan.

5. Target PPA adalah terciptanya aparatur pemerintah yang memiliki jati diri sesuai dengan nilai agama, sehingga malu berbuat dosa, menghindari dari segala bentuk penyimpangan.

6. PPA menjiwai pemberdayaan pengawasan fungsional, pengawasan melekat dan pengawasan masyarakat. ${ }^{29}$

Sejalan dengan hal tersebut, Dr. Atiqullah, M.Pd menyatakan bahwa pengawasan pendekatan agama Islam adalah pembudayaan pengawasan dengan menyampaikan pesan moral yang dilandasi oleh nilai-nilai agama Islam sehingga bermanfaat dalam pelaksanaan pengawasan fungsional, pengawasan melekat, dan pengawasan masyarakat dalam rangka mencapai keberhasilan suatu program. ${ }^{30}$

${ }^{29}$ http://ppaitjen.blogspot.co.id/. Diakses hari Sabtu 14 Maret 2020.

${ }^{30}$ Atiqullah, Manajemen \& Kepemimpinan, 32-33. 
Adapun langkah yang ditempuh dalam proses pengawasan yang diajukan oleh Robbins dan Coulter sebagaimana yang dipaparkan Setyowati adalah sebagai berikut: ${ }^{31}$

1. Mengukur kinerja sebenarnya. Terdapat beberapa sumber informasi yang dapat digunakan seorang pengawas dalam melakukan kinerja sebenarnya, yaitu: pengamatan pribadi, laporan lisan, dan laporanlaporan tertulis.

2. Membandingkan kinerja sebenarnya dengan suatu standar.

3. Mengambil tindakan manajerial untuk membetulkan penyimpanganpenyimpangan atau standar yang tidak memadai.

Berbeda halnya dengan apa yang dilakukan oleh Herman dan Jamaluddin Idris, dalam penelitiannya yang berjudul "Pendekatan Ibadah sebagai Model Supervisi untuk Meningkatkan Kinerja Guru Pendidikan Agama Islam" mereka menggunakan lima nilai ibadah yang menjadi prinsip dalam bekerja yang diterapkan melalui pendekatan ibadah. Lima prinsip tersebut yaitu:

1. Bekerja semata-mata karena-Nya

2. Bekerja sebagai sarana komunikasi dengan-Nya

3. Lambang ketundukan dan ketaatan pada-Nya

4. Semua pekerjaan dinilai sebagai ibadah

5. Tidak mengenal waktu dan tempat dalam bekerja untuk meningkatkan kinerja guru. ${ }^{32}$

Pengamalan nilai-nilai keagamaan mempunyai daya tangkal yang efektif terhadap kecenderungan perilaku menyimpang, mengumbar nafsu, bertindak diluar batas kemanusiaan atau norma hukum yang berlaku, melakukan KKN serta perilaku negatif lainnya. Disamping itu, setiap agama mengajarkan untuk mengamalkan nilai-nilai kebaikan, kejujuran, dan bekerja keras dalam bekerja.

Atas dasar hal tersebut, dalam website literasi publik yang di post pada 31 Maret 2019 dijelaskan bahwa dalam mempraktekkan Pengawasan Pendekatan Agama (PPA) dilaksanakan melalui beberapa pendekatan, yaitu:

1. Pendekatan rasional

\footnotetext{
${ }^{31}$ Setyowati, Organisasi dan Kepemimpinan Modern, 156.

${ }^{32}$ Herman dan Jamaulddin Idris, “Pendekatan Ibadah... ”, 78.
} 
Pendekatan rasional dilakukan melalui penanaman nilai-nilai keagamaan yang berkaitan dengan pengertian dan hakikat pengawasan. Selain itu, juga dapat dilakukan dengan menggunakan pemikiran logis dan argumentatif yang dapat diterima akal sehat.

2. Pendekatan afektif

Pendekatan afektif dilakukan dengan penanaman nilai-nilai agama yang berkaitan dengan pengawasan dan menyentuh hati nurani. Melalui pendekatan ini diharapkan agar perilaku masyarakat selalu dalam keseimbangan antara pertimbangan akal sehat dengan penghayatan hati nurani sesuai sesuai dengan fitrah kemanusiaan.

3. Pendekatan pembiasaan

Pendekatan pembiasaan dilakukan melalui upaya penanaman nilai-nilai agama dalam pengawasan melalui penanaman tata nilai positif yang berkembang di masyarakat.

4. Pendekatan keteladanan.

Pendekatan keteladana ditunjukkan melalui penanaman nilai-nilai agama dalam pengawasan melalui contoh atau tauladan yang baik dari aparatur negara dan para tokoh terhadap masyarakat pada umumnya. ${ }^{33}$

Sasaran program pengawasan dalam dunia pendidikan Islam agar para ustadz terbebas dari perilaku penyimpangan berupa kolusi, korupsi, nepotisme. Peran pimpinan dalam suatu institusi Islam sangat penting bagi pembentukan mental dan moral spiritual generasi muslim sehingga sebagai pendidik, pembimbing, dan pengasuh harus mampu memahami bahwa:

1. Pekerjaan mendidik, membimbing, dan mengasuh adalah aktivitas mulya.

2. Kemulyaan pekerjaan mendidik, membimbing, dan mengasuh itu harus diimbangi dengan ketinggian etika dan tanggung jawab.

33 https://www.literasipublik.com/pengawasan-melalui-pendekatan-agama-ppa. Diakses pada hari Senin 6 Juli 2020. 
3. Pendidik, pembimbing, dan pengasuh dalam institusi keagamaan harus selalu mengaitkan pelaksanaan kerjanya dengan harapan untuk mendapatkan keridhaan Allah SWT. di dunia dan akhirat nanti. ${ }^{34}$

\section{H. HAL-HAL YANG MEMPENGARUHI PENGAWASAN}

Menurut Ali Imron, ada beberapa faktor yang mempengaruhi pengawasan, antara lain: ${ }^{35}$

1. Waktu yang dipergunakan untuk pengawasan. Semakin banyak waktu yang disediakan oleh pengawas untuk melakukan pengawasan, maka semakin kaburlah gambaran mengenai hal-hal yang diawasi.

2. Kapasitas mental dan daya suai pribadi pengawas. Makin baik kapasitas mental dan daya suai pengawas terhadap hal-hal yang diawasi, maka semakin efektif pengawasan. ${ }^{36}$

3. Kompleksitas hal-hal yang diawasi. Semakin komplek hal-hal yang diawasi, semakin banyak energi yang dibutuhkan dan dikeluarkan untuk melakukan pengawasan dan sebaliknya.

4. Tugas-tugas lain dari ekskutif. Seorang supervisior yang memiliki tugas rangkap akan mengurangi kefektifan pengawasannya.

5. Stabilitas operasi. Semakin stabil operasi pengawasan yang dilakukan, maka gambaran terhadap sesuatu yang diawasi akan semkain detail.

6. Kemampuan dan pengalaman bawahan. Bawahan dengan kemampuan yang tinggi dan dengan pengalaman yang banyak akan mudah sekali diawasi dan bahkan sedikit sekali membutuhkan pengawasan dibanding yang tidak mampu dan tidak berpengalaman.

\section{KESIMPULAN}

Pengawasan yang dikenal dengan istilah supervisi adalah sebuah upaya pengamatan yang dilakukan oleh seorang atasan terhadap bawahannya melalui kegiatan bimbingan, pembinaan, dan pengarahan terhadap personil (pelaku) atau lembaga pendidikan, dengan tujuan untuk mengendalikan kegiatan agar sesuai dengan rencana yang telah

${ }^{34}$ Atiqullah, Manajemen \& Kepemimpinan, 33-34.

${ }^{35}$ Imron, Proses Manajemen Tingkat Satuan Pendidikan, 146\&147.

${ }^{36}$ Miftahul Ulum, "Fikih Organisasi (Reaktualisasi Sejarah Nahdlatul Ulama di Indonesia)”, Al-Insyiroh Jurnal Studi Keislaman, Vol. 5 Nomor 2 (September 2019), 74. 
ditetapkan sehingga hasil pelaksanaan pekerjaan diperoleh secara efisien dan efektif sesuai dengan rencana yang telah ditentukan dalam program kegiatan.

Berdasarkan hal tersebut dapat dipahami bahwa metodologi pengawasan dengan pendekatan agama (PPA) adalah bentuk pengawasan melalui pemberdayaan nilai-nilai agama dalam mendorong terciptanya pengawasan diri (self control) dan jati diri aparatur pemerintah yang bersih dan terhindar dari penyimpangan.

Pengamalan nilai-nilai keagamaan mempunyai daya tangkal yang efektif terhadap kecenderungan perilaku menyimpang, mengumbar nafsu, bertindak diluar batas kemanusiaan atau norma hukum yang berlaku, melakukan KKN serta perilaku negatif lainnya. Disamping itu, setiap agama mengajarkan untuk mengamalkan nilai-nilai kebaikan, kejujuran, dan bekerja keras dalam bekerja.

Pengawas merupakan penjamin, peningkat, dan pengawas mutu pendidikan yang memiliki keunggulan kompetitif dan komparatif. Karenaya, tujuan supervisi pendidikan adalah meningkatkan kemampuan profesional dan teknis bagi guru, kepala sekolah, dan personel sekolah lainnya agar proses pendidikan disekolah lebih berkualitas. Dan yang utama, supervisi pendidikan dilakukan atas dasar kerjasama, partisipasi, dan kolaborasi, bukan paksaan dan kepatuhan. Dengan demikian, akan timbul kesadaran, inisiatif, dan kreativitas personil sekolah.

Berdasar pada hal tersebut, seorang pengawas harus memiliki standar Kualifikasi dan kompetensi sebagaimana yang ditetapkan dalam Permendiknas No. 12 Tahun 2007 tentang Standar Pengawas Sekolah/Madrasah supaya bisa menjalankan tugas dan fungsi pengawasannya dengan baik.

Disamping adanya kualifikasi dan kompetensi yang harus dimiliki oleh seorang pengawas, terdapat beberapa faktor yang juga sangat berpengaruh terhadap keberhasilan dan kelancaran pelaksanaan pengawasan. Faktor-faktor tersebut antara lain: Waktu yang dipergunakan untuk pengawasan, kapasitas mental dan daya sesuai pribadi pengawas, kompleksitas hal-hal yang diawasi, tugas-tugas lain 
dari ekskutif, stabilitas operasi, serta kemampuan dan pengalaman bawahan.

\section{DAFTAR PUSTAKA}

Arisandi, B. (2015). Ujian Nasional Mengkebiri Kedaulatan Guru. AlInsyiroh: Jurnal Studi Keislaman, 1(1), 1-22.

Atiqullah. 2010. Manajemen \& Kepemimpinan Pendidikan Islam. Pamekasan: STAIN Pamekasan Press.

Mengefektifkan Lembaga Pendidikan Agama \& Pendidikan Keagamaan. Surabaya: Pena Salsabila.

Barnawi \& Muhammad Arifin. 2014. Meningkatkan Kinerja Pengawas

Sekolah: Upaya Upgrade Kapasitas Kerja Pengawas Sekolah.

Yogyakarta: Ar-Ruzz Media.

Herabudin. 2009. Administrasi dan Supervisi Pendidikan. Bandung: Pustaka Setia.

Herman dan Jamaluddin Idris, "Pendekatan Ibadah sebagai Model Supervisi untuk Meninglatkan Kinerja Guru Pendidikan Agama Islam",

DAYAH: Journal of Islamic Education, Volume 3 No.1, (2020).

https://www.literasipublik.com/pengawasan-melalui-pendekatan-agama-

ppa. Diakses pada hari Senin 6 Juli 2020.

http://ppaitjen.blogspot.co.id/. Diakses hari Sabtu 14 Maret 2020.

Imron, Ali. 2012. Supervisi Pembelajaran Tingkat Satuan Pendidikan. Jakarta: Bumi Aksara.

2013. Proses Manajemen Tingkat Satuan Pendidikan. Jakarta:

Bumi Aksara.

Jasmani \& Syaiful Mustofa. 2013. Supervisi Pendidikan: Terobosan Baru dalam Peningkatan Kinerja Pengawas Sekolah dan Guru. Yogyakarta: Ar-Ruzz Media.

Junaidi, J. (2015). Pendidikan Islam (Kedudukan dan Jenis Menurut UndangUndang). Al-Insyiroh: Jurnal Studi Keislaman, 1(1), 105116.

Kompri. 2015. Manajemen Pendidikan: Komponen-Komponen Elementer Kemajuan Sekolah. Yogyakarta: Ar-Ruzz Media. 
Makawimbang, Jerry H. 2012. Kepemimpinan Pendidikan yang Bermutu. Bandung: Alfabeta.

Mulyasa, E. 2012. Manajemen Berbasis Sekolah. Bandung: PT Remaja Rosdakarya.

Setyowati. 2013. Organisasi dan Kepemimpinan Modern. Yogyakarta: Graha Ilmu.

Sudirman, Murniati AR dan Bahrun, "Manajemen Pengawas Pada Kantor Kementerian Agama Kabupaten Simeulue", Jurnal Magister Administrasi Pendidikan, Vol. 5 No.3, (Agustus, 2017).

Tim Penyusun Kamus Pusat Bahasa. 2008. Kamus Besar Bahasa Indonesia. offline. Jakarta: Pusat Bahasa.

Wahyudi. 2012. Kepemimpinan kepala Sekolah dalam Organisasi Pembelajar (Learning Organization). Bandung: Alfabeta.

Yahya, Murip. 2013. Profesi Tenaga Kependidikan. Bandung: Pustaka Setia. Ulum, Miftahul. "Metodologi Studi Islam (Spiritualitas Dalam Pendidikan Islam Dalam Pandangan Syed Muhammad Naquib Al-Attas)”, AlIman: Jurnal Studi Keislaman dan Kemasyarakatan, Vol. 4 Nomor 1 (22 Maret 2020).

Ulum, Miftahul. "Fikih Organisasi (Reaktualisasi Sejarah Nahdlatul Ulama di Indonesia)”, Al-Insyiroh Jurnal Studi Keislaman, Vol. 5 Nomor 2 (September 2019).

Ulum, Miftahul. "The Concept of Maslahah By Al-Imam Malik And Al-Imam Al-Tufi (Comparatif Study of Maslahah Al-Imam Malik and Al-Imam Najm al-Din Al-Tufi)", Veteran Law Review, Vol. 2, No. 1 (November, 2018). 